\begin{tabular}{|c|c|c|c|c|c|c|}
\hline \multirow{4}{*}{ Impact Factor: } & ISRA (India) & $=3.117$ & SIS (USA) & $=0.912$ & ICV (Poland) & $=6.630$ \\
\hline & ISI (Dubai, UAE & $=0.829$ & РИНЦ (Russia & $=0.156$ & PIF (India) & $=1.940$ \\
\hline & GIF (Australia) & $=0.564$ & ESJI (KZ) & $=8.716$ & IBI (India) & $=4.260$ \\
\hline & JIF & $=1.500$ & SJIF (Morocco & $=5.667$ & OAJI (USA) & $=0.350$ \\
\hline
\end{tabular}

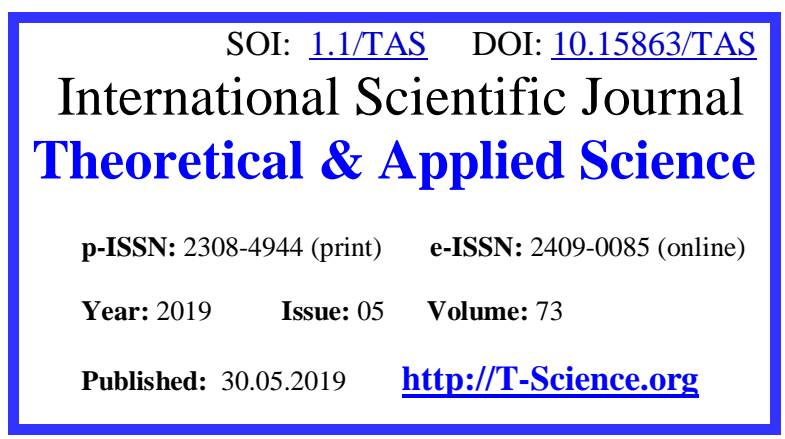

SECTION 7. Mechanics and machine construction.
QR - Issue
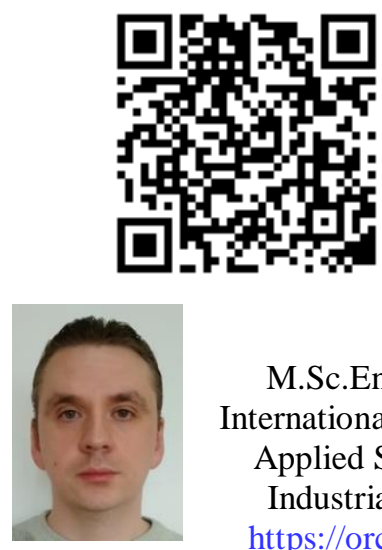

QR - Article

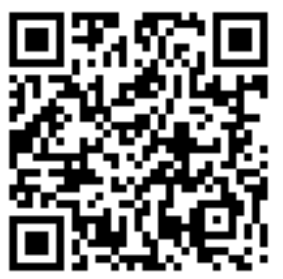

Denis Chemezov

M.Sc.Eng., Corresponding Member of International Academy of Theoretical and Applied Sciences, Lecturer of Vladimir Industrial College, Russian Federation https://orcid.org/0000-0002-2747-552X chemezov-da@yandex.ru

Andrey Kartsev

"Stroipotentsial" LLC, Equipment Adjuster, Student of Vladimir Industrial College, Russian Federation

Andrey Komissarov Master of Industrial Training, Vladimir Industrial College, Russian Federation

Ivan Kanishchev Student of Vladimir Industrial College, Russian Federation

Ivan Moiseev Student of Vladimir Industrial College, Russian Federation

Evgeniy Polikarpov Student of Vladimir Industrial College,

Russian Federation

Andrey Kalinin

Student of Vladimir Industrial College,

Russian Federation

\title{
DESIGNING AND MANUFACTURING OF SHAPING PARTS OF A DIE MOLD
}

Abstract: Manufacturing stages of a die mold were considered in the article. Attention was paid to computer designing and subsequent manufacturing of the die mold shaping parts and tools of the second order (copper electrodes).

Key words: a die mold, an insert, designing, machining, an operation, a machine.

Language: English

Citation: Chemezov, D., et al. (2019). Designing and manufacturing of shaping parts of a die mold. ISJ Theoretical \& Applied Science, 05 (73), 461-466.

Soi: http://s-o-i.org/1.1/TAS-05-73-70 Doi: crossef https://dx.doi.org/10.15863/TAS.2019.05.73.70

\section{Introduction}

A die mold consists of many groups of parts, each of which performs its a specific technological function. The parts group of the die mold, responsible for shaping of a casting, is the most complex and timeconsuming. This group of the parts is $70 \%$ of cost of the entire die mold. High requirements for accuracy, physical and mechanical properties, surfaces 


\begin{tabular}{|c|c|c|c|c|c|c|}
\hline \multirow{4}{*}{ Impact Factor: } & ISRA (India) & $=3.117$ & SIS (USA) & $=0.912$ & ICV (Poland) & $=6.630$ \\
\hline & ISI (Dubai, UAE & $=0.829$ & РИНЦ (Russia & $=0.156$ & PIF (India) & $=1.940$ \\
\hline & GIF (Australia) & $=0.564$ & ESJI (KZ) & $=8.716$ & IBI (India) & $=4.260$ \\
\hline & JIF & $=1.500$ & SJIF (Morocce & $=5.667$ & OAJI (USA) & $=0.350$ \\
\hline
\end{tabular}

roughness and manufacturability are imposed to the parts $[1-10]$. Designing stages and production of the shaping parts of the die mold are considered in this article.

\section{Technological part}

The designed die mold consists of two inserts (upper and lower), the cylindrical signs (the rods) and the rectangular signs (the inserts). Cavities of gating channels and the shaping cavities are performed on the inserts. The channels for melt injection into the shaping cavities of the die mold are performed in the lower insert. The minimum diameter of the conical channel for melt injection is $0.6 \mathrm{~mm}$. The inserts are made of 1.2379 (EN) steel. Material hardness of the lower and upper inserts after heat treatment should be 58...62 HRC. Four castings are simultaneously poured into the die mold. The three-dimensional solid model of the die mold is presented in the Fig. 1.
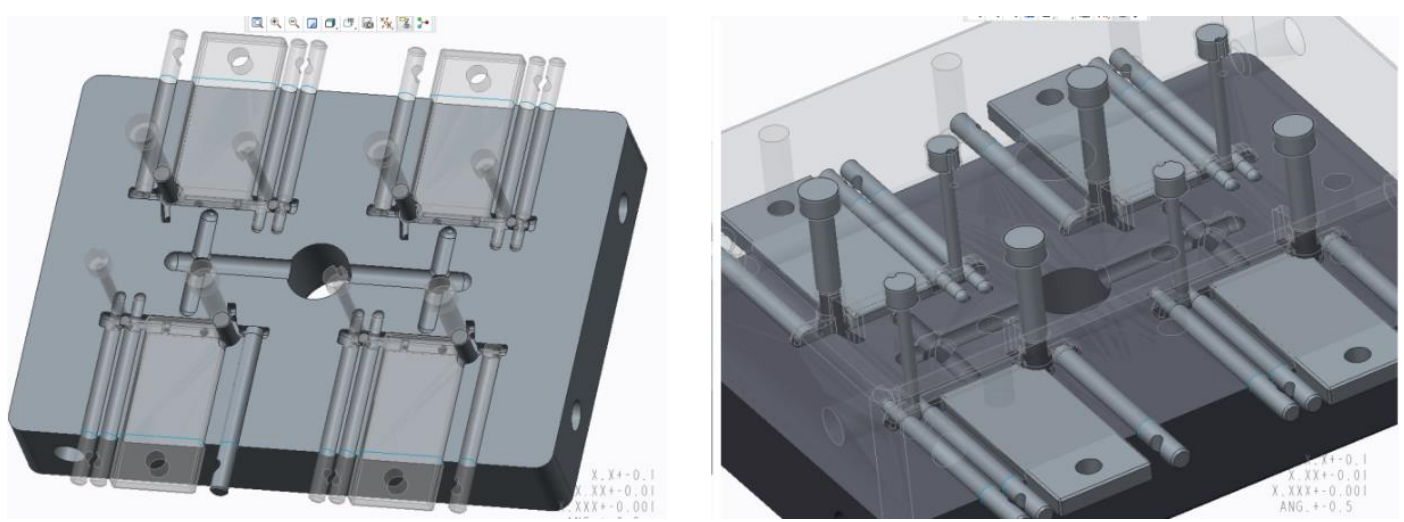

Figure 1 - The three-dimensional solid models of the die mold parts in assembly.

The cylindrical and rectangular signs are placed in the shaping cavities of the upper and lower inserts. These signs form the outer and inner surfaces of the casting. Roughness of the contact surfaces of the rods should be $0.32 \ldots 2.5 \mu \mathrm{m}$. The signs are made of 1.2108 (EN) steel. Hardness of the signs material is $49 . . .53$
HRC. Roughness of the contact surfaces of the rectangular sign should be $0.63 \ldots 1.25 \mu \mathrm{m}$.

The three-dimensional solid models of the shaping signs of the die mold are presented in the Fig. 2 .

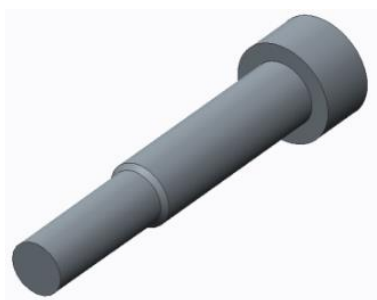

$\boldsymbol{A}$

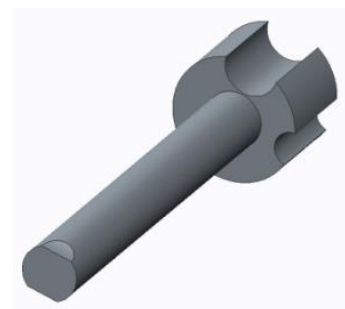

$\boldsymbol{D}$

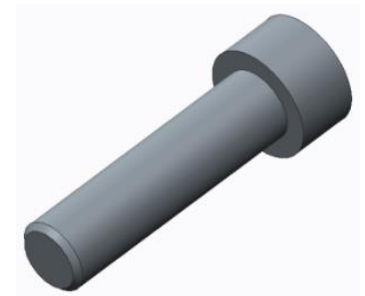

$\boldsymbol{B}$

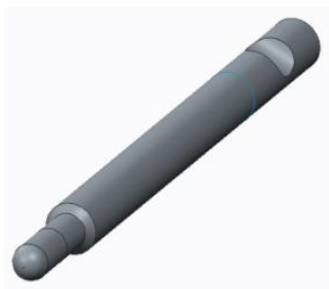

$\boldsymbol{E}$

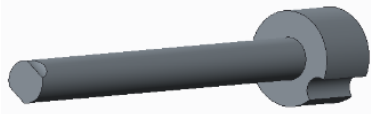

C

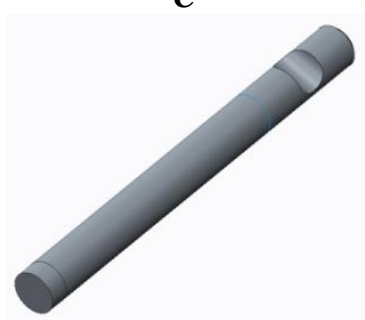

$\boldsymbol{F}$

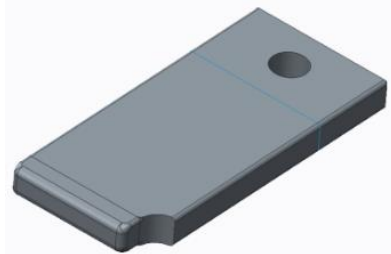

$G$

Figure 2 - The three-dimensional solid models of the cylindrical and rectangular signs: $A-F$ - the rods; $G$ - the insert.

Operations of a technological process of manufacturing of the main shaping parts of the die mold are described in the table 1 . The technological process consists of 13 operations. Processing is carried out on the universal machines and on the machines with numerical control. Grinding is carried out by a grinding wheel (graininess - 2000). 


\begin{tabular}{|c|c|c|c|c|c|c|}
\hline \multirow{4}{*}{ Impact Factor: } & ISRA (India) & $=3.117$ & SIS (USA) & $=0.912$ & ICV (Poland) & $=6.630$ \\
\hline & ISI (Dubai, UAE & $=0.829$ & РИНЦ (Russia & $=0.156$ & PIF (India) & $=1.940$ \\
\hline & GIF (Australia) & $=0.564$ & ESJI (KZ) & $=8.716$ & IBI (India) & $=4.260$ \\
\hline & JIF & $=1.500$ & SJIF (Morocce & $=5.667$ & OAJI (USA) & $=0.350$ \\
\hline
\end{tabular}

Table 1. The processing technology of the parts "Insert".

\begin{tabular}{|c|c|c|}
\hline The operation & The operation description & The equipment \\
\hline Blanking & Cutting of a billet with allowances of $2.5 \mathrm{~mm}$ on a side. & $\begin{array}{l}\text { The band saw } \\
\text { "Pegas" }\end{array}$ \\
\hline Milling & Milling of the billet with six sides with allowance of $1.25 \mathrm{~mm}$ on the side. & $\begin{array}{l}\text { The milling } \\
\text { machine } \\
\text { "WM121M" }\end{array}$ \\
\hline Grinding & $\begin{array}{l}\text { Grinding of the billet with six sides to the angle of } 90^{\circ} \text { with allowance of } \\
0.4 \mathrm{~mm} \text { on the side. }\end{array}$ & $\begin{array}{l}\text { The grinding } \\
\text { machine } \\
\text { "3L722A" }\end{array}$ \\
\hline $\begin{array}{l}\text { Coordinate } \\
\text { boring }\end{array}$ & $\begin{array}{l}\text { Drilling and boring of holes for the signs, the ejectors and the gate bushing; } \\
\text { drilling of the holes for fastener. }\end{array}$ & $\begin{array}{l}\text { The coordinate } \\
\text { boring machine } \\
\text { "2N135" }\end{array}$ \\
\hline Locksmithing & $\begin{array}{l}\text { Drilling of the holes for threads and the cooling channels; threading } \\
\text { according to a drawing. }\end{array}$ & \\
\hline $\begin{array}{l}\text { Coordinate } \\
\text { milling }\end{array}$ & $\begin{array}{l}\text { Milling of the shaping cavities and the cavities for the signs, the gating } \\
\text { channels, the retainer of the gate bushing and the technological holes for } \\
\text { the pins previously with allowance of } 0.4 \mathrm{~mm} \text { on the side, fillets on the } \\
\text { corners completely. }\end{array}$ & $\begin{array}{l}\text { The machining } \\
\text { center "C-tek KM } \\
80 "\end{array}$ \\
\hline Thermal & $\begin{array}{l}\text { Hardening of the billet according to the drawing up to } 58 \ldots 62 \mathrm{HRC} \text {. The } \\
\text { heat treatment modes: holding } 4 \text { hours in coal at the temperature of } 1000 \\
{ }^{\circ} \mathrm{C} \text {, cooling with oil, tempering } 3 \text { hours at the temperature of } 250{ }^{\circ} \mathrm{C} \text {. }\end{array}$ & \\
\hline Grinding & $\begin{array}{l}\text { Grinding of the billet with six sides to the angle of } 90^{\circ} \text { with allowance of } \\
0.1 \mathrm{~mm} \text { on the side. }\end{array}$ & $\begin{array}{l}\text { The grinding } \\
\text { machine } \\
\text { "3L722A" }\end{array}$ \\
\hline $\begin{array}{l}\text { Coordinate } \\
\text { boring }\end{array}$ & Boring of the technological holes for the pins completely. & $\begin{array}{l}\text { The coordinate } \\
\text { boring machine } \\
\text { "2N135" }\end{array}$ \\
\hline $\begin{array}{l}\text { Coordinate } \\
\text { milling }\end{array}$ & $\begin{array}{l}\text { Milling of the gating channels, the cavities for the signs, the cavities for the } \\
\text { rectangular signs completely, the shaping cavities preliminary with } \\
\text { allowance of } 0.1 \mathrm{~mm} \text { on the side for performing of the electrical discharge } \\
\text { operation. }\end{array}$ & $\begin{array}{l}\text { The machining } \\
\text { center "C-tek KM } \\
80 "\end{array}$ \\
\hline Grinding & $\begin{array}{l}\text { Grinding of the insert in assembly on the pins with four sides completely } \\
\text { according to the drawing; allowance is distributed evenly. }\end{array}$ & $\begin{array}{l}\text { The grinding } \\
\text { machine } \\
\text { "3L722A" }\end{array}$ \\
\hline $\begin{array}{l}\text { Electrical } \\
\text { discharge }\end{array}$ & $\begin{array}{l}\text { Burning of the inserts by special electrodes. The channels for injection in } \\
\text { the gating channels, the shaping cavities, three shaping grooves are burned } \\
\text { on the insert "08". Permissible roughness in accordance with the sample } \\
\text { No. } 28 \text {. The shaping cavities are burned by the special electrodes on the } \\
\text { insert "09". }\end{array}$ & $\begin{array}{l}\text { The EDM } \\
\text { "SODICK } \\
\text { AM55L" }\end{array}$ \\
\hline $\begin{array}{l}\text { Electrical } \\
\text { discharge }\end{array}$ & $\begin{array}{l}\text { Burning of the cavities for the cylindrical signs by the special electrodes in } \\
\text { the inserts in assembly. The inserts " } 08 \text { " and " } 09 \text { " are assembled on the pins } \\
\text { for achieving of the highest accuracy of the cavities. }\end{array}$ & $\begin{array}{l}\text { The EDM } \\
\text { "SODICK } \\
\text { AM55L" }\end{array}$ \\
\hline
\end{tabular}

Designing of mechanical and electrical discharge processing of the shaping surfaces on the parts of the die mold in the PTC Creo software environment is presented in the Fig. 3. Final processing of the gating channels and preliminary processing of the shaping cavities in the inserts are carried out by milling. Machining is carried out by the three-dimensional model of the part. A trajectory of a cutting tool is presented by red lines. The tools of the second order (the special copper electrodes) must be processed for final processing of the inserts on the EDM machine. The electrodes are processed in parallel to manufacturing of the inserts. The shaping cavity of the insert is processed by the first electrode. Three grooves are processed by the second electrode. 


\begin{tabular}{|c|c|c|c|c|c|c|}
\hline \multirow{4}{*}{ Impact Factor: } & ISRA (India) & $=3.117$ & SIS (USA) & $=0.912$ & ICV (Poland) & $=6.630$ \\
\hline & ISI (Dubai, UAE & $=0.829$ & РИНЦ (Russia & $=0.156$ & PIF (India) & $=1.940$ \\
\hline & GIF (Australia) & $=0.564$ & ESJI (KZ) & $=8.716$ & IBI (India) & $=4.260$ \\
\hline & JIF & $=1.500$ & SJIF (Morocco & $=5.667$ & OAJI (USA) & $=0.350$ \\
\hline
\end{tabular}
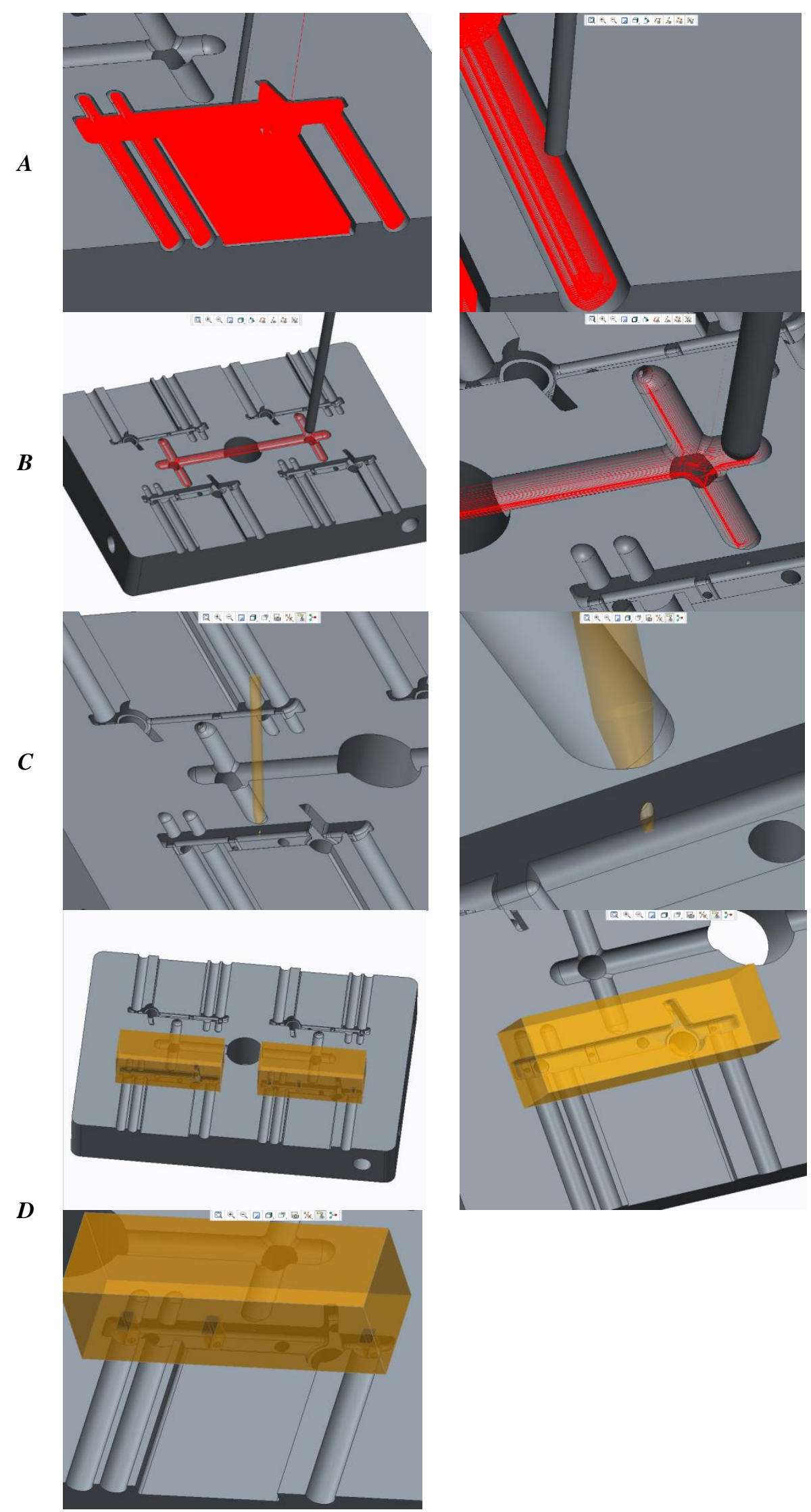

Figure 3 - Processing designing of the shaping surfaces: $A$ - the cavities for the cylindrical and rectangular signs; $B$ - the gating channels; $C$ - the channels for melt injection in the gating channels; $D$ - the shaping cavities and three grooves. 


\begin{tabular}{llllll} 
& ISRA (India) $=\mathbf{3 . 1 1 7}$ & SIS (USA) $=\mathbf{0 . 9 1 2}$ & ICV (Poland) & $\mathbf{= 6 . 6 3 0}$ \\
Impact Factor: & ISI (Dubai, UAE) $=\mathbf{0 . 8 2 9}$ & PUHЦ (Russia) $=\mathbf{0 . 1 5 6}$ & PIF (India) & $=\mathbf{1 . 9 4 0}$ \\
& GIF (Australia) $=\mathbf{0 . 5 6 4}$ & ESJI (KZ) & $\mathbf{8 . 7 1 6}$ & IBI (India) & $=\mathbf{4 . 2 6 0}$ \\
& JIF & $\mathbf{1 . 5 0 0}$ & SJIF (Morocco) $=\mathbf{5 . 6 6 7}$ & OAJI (USA) & $\mathbf{0 . 3 5 0}$ \\
\hline
\end{tabular}

The some operations of the technological process of manufacturing of the die mold are shown in the Fig. 4. The main operation of obtaining of the gating channels and the shaping cavities of the insert is presented in the photos of $A$ and $B$. The photos of $C$ - $G$ demonstrate the manufacturing process of the tools of the second order. The rectangular signs are processed in the photos of $H$ and $I$.
$A$

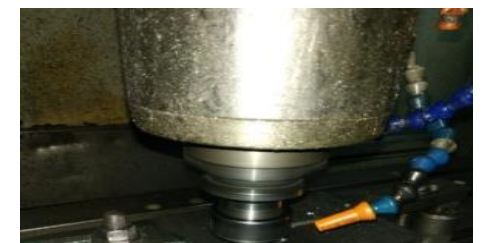

$D$

$\boldsymbol{G}$

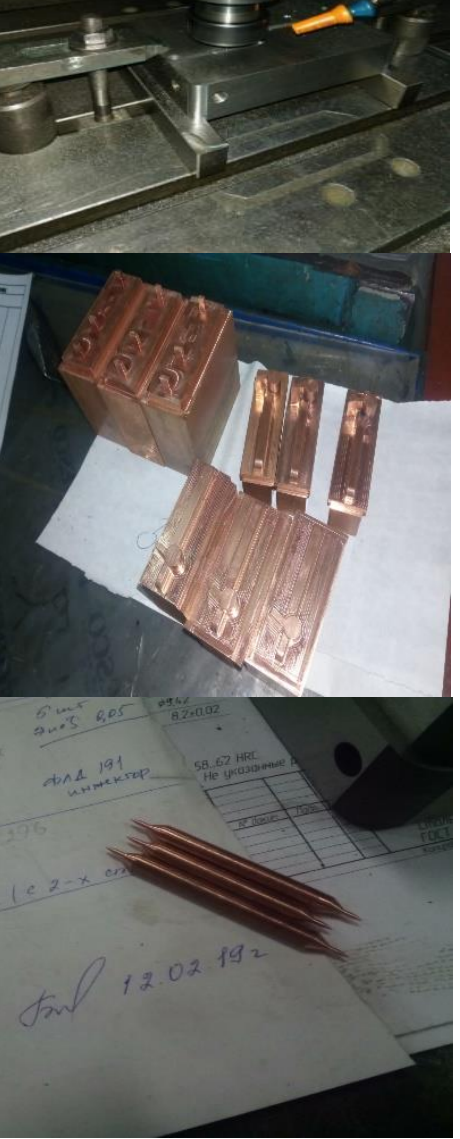

$\boldsymbol{B}$

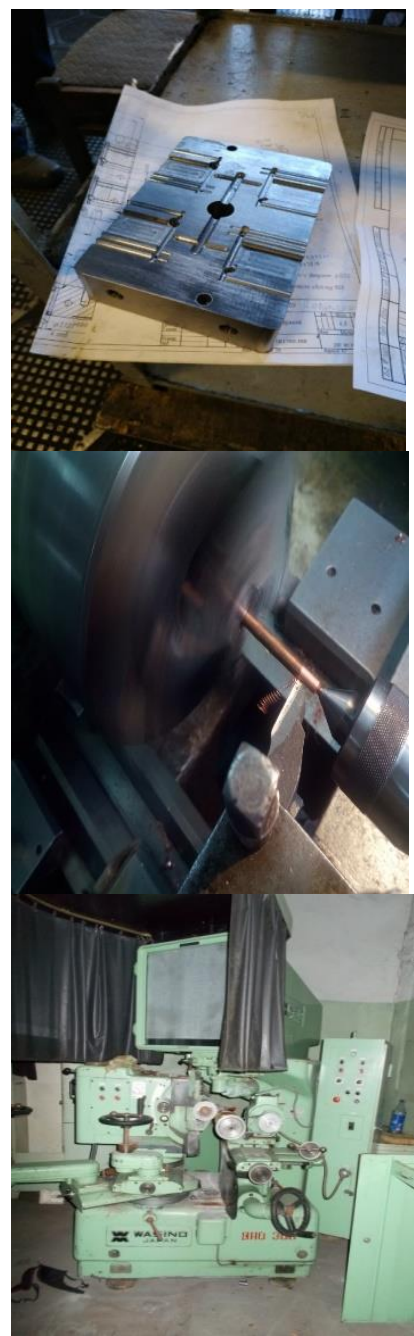

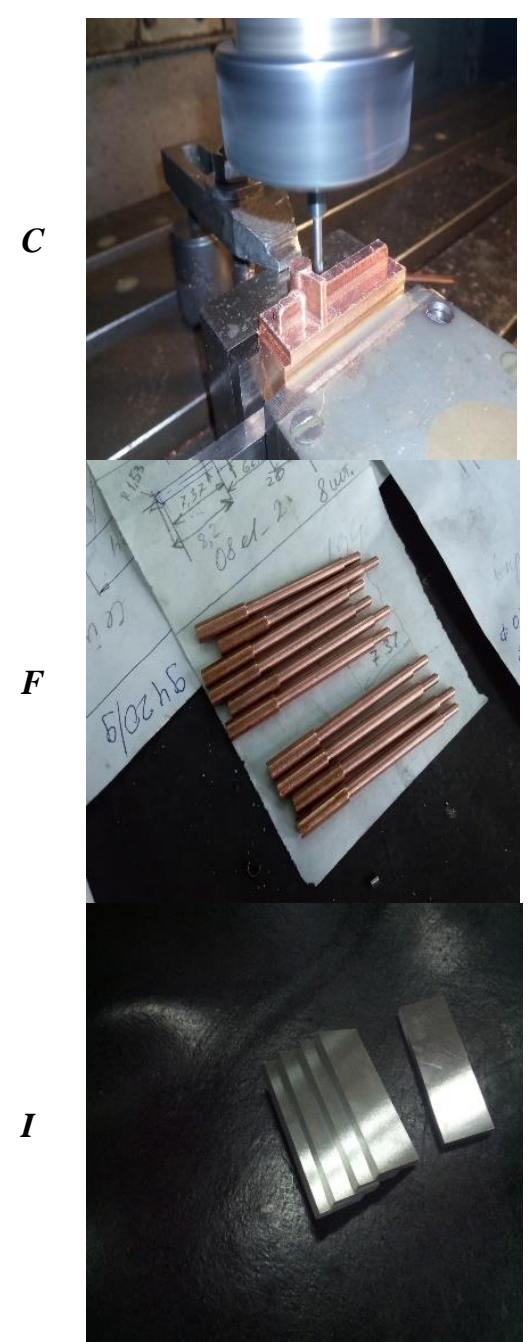

Figure 4 - The operations of the technological process of manufacturing of the die mold: $A$ - milling of the gating channels and the cavities for the signs; $\boldsymbol{B}$ - the billet after milling; $\boldsymbol{C}$ - a profile milling of the copper electrode for burning of the cavities for the signs; $D$ - the processed copper electrodes; $E$ - turning of the

cylindrical electrodes; $F$ and $G$ - the processed cylindrical electrodes; $H$ - the machine "GLS-125a WASINO" for optical grinding; $I$ - the billets of the rectangular signs after grinding.

The cylindrical signs are processed on the following technological equipment:

$A$. The lathe "16K20". Turning of a contour with allowance of $0.8 \mathrm{~mm}$.

B. A furnace. Hardening of the signs according to the drawing. The heat treatment modes: holding 20 minutes at the temperature of $850{ }^{\circ} \mathrm{C}$, cooling in oil, tempering one hour at the temperature of $500{ }^{\circ} \mathrm{C}$, air cooling.

C. The grinding machine "Karstens AS 15 A". Grinding of the signs in a size.
$D$. The optical grinding machine "GLS-125a WASINO". Grinding of the cylindrical grooves and slopes on the signs according to the drawing.

The designed three-dimensional solid model of the casting is presented in the Fig. 5 .

The casting is made of MIM 4140 alloy. A volume of the casting material is designed with shrinkage of $18 \%$. The casting slopes are performed in direction of reducing of the sizes. The ejector marks with the depth of not more than $0.1 \mathrm{~mm}$ are allowed on the some casting surfaces. 


\begin{tabular}{llllll} 
& ISRA (India) $=\mathbf{3 . 1 1 7}$ & SIS (USA) & $=\mathbf{0 . 9 1 2}$ & ICV (Poland) & $=\mathbf{6 . 6 3 0}$ \\
Impact Factor: & ISI (Dubai, UAE) $=\mathbf{0 . 8 2 9}$ & PUHL (Russia) $=\mathbf{0 . 1 5 6}$ & PIF (India) & $=\mathbf{1 . 9 4 0}$ \\
& GIF (Australia) $=\mathbf{0 . 5 6 4}$ & ESJI (KZ) & $=\mathbf{8 . 7 1 6}$ & IBI (India) & $=\mathbf{4 . 2 6 0}$ \\
& JIF & $\mathbf{1 . 5 0 0}$ & SJIF (Morocco) $=\mathbf{5 . 6 6 7}$ & OAJI (USA) & $\mathbf{0 . 3 5 0}$ \\
\hline
\end{tabular}
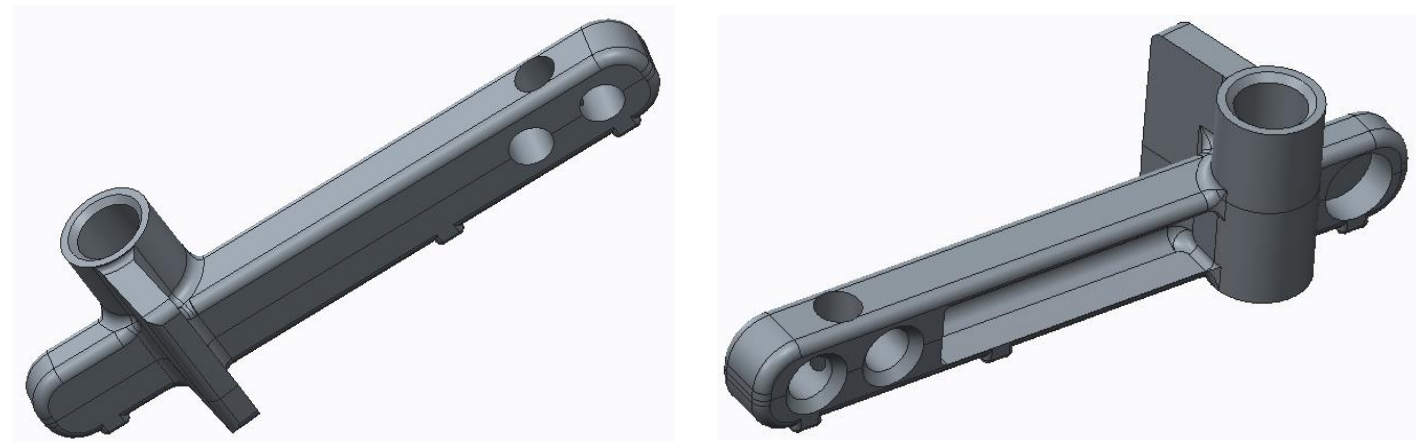

Figure 5 - The three-dimensional solid model of the casting.

The assembled die mold is subjected to mechanical finishing and testing under the different operating conditions for obtaining of the best results after manufacturing of all the parts.

\section{Conclusion}

Designing of the shaping parts of the die mold includes the development and manufacturing of the tools of the second order for sequential processing of the shaping surfaces. The complex shaping surface on the inserts is processed by means of the rough, semifinishing and finishing profile electrodes. Configuration and orientation of the cylindrical and rectangular signs in the inserts are presented.

\section{References:}

1. Chemezov, D. (2018). Special tooling for manufacturing of automotive components: processing technology of the part "Insert" and assembly of a mold for injection molding. ISJ Theoretical \& Applied Science, 04 (60), 1-8.

2. Chemezov, D. (2017). Designing and manufacturing of the tool of the second order. ISJ Theoretical \& Applied Science, 02 (46), 163 172.

3. Sokolov, A. P., \& Filippenko, N. G. (2014). Technology of manufacturing of molds for receiving the gasified models. Young scientist, №1, 120-122.

4. Sapchenko, I. G., Zhilin, S. G., \& Komarov, O. N. (2007). Features of the molds design in casting on the melted models. Casting and Metallurgy, 1(41), 93-95.

5. Voronchagin, M. A., \& Sinyavin, A. V. (2017). Calculation and design of molds for casting products under pressure. IX International student scientific conference "Student scientific forum - 2017".

6. Pershin, N. S., \& Chepchurov, M. (2015). Manufacturing the formative mold parts of composite materials. The Russian Automobile and Highway Industry Journal, 6(46), 76-81.

7. Yatsenko, O. V. (2006). Analysis of collectability in the design of molds. The Bulletin of Irkutsk State University, 4(28), 30-36.

8. Potemkin, V. Y., Sanova, L. A., \& Tyagunova, Z. V. (2016). Production of matrixes of compression moulds by the galvanoplasty method. Electronic journal: Science, technology and education, 4(9), 1-7.

9. Tang, S. H. (2006). Design and thermal analysis of plastic injection mould. Journal of Materials Processing Technology, 171(2), 259-267.

10. (n.d.). GOST 27358-87. Press moulds for manufacturing of plastic articles. General specifications. 